\section{Oppdatert og lettlest kardiologi}

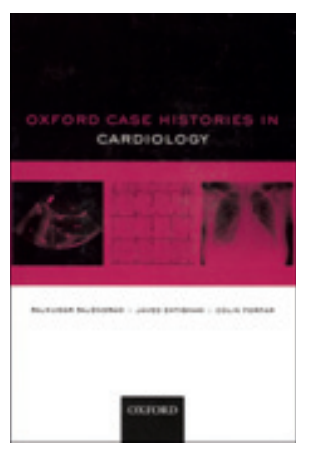

Rajkumar Rajendram, Javed Ehtisham Colin Forfar

Oxford case histories in cardiology

412 s, tab, ill. Oxford: Oxford University Press, 2011. Pris GBP 40

ISBN 978-0-19-955678-6

Dette er en lettlest fremstilling som er meget aktuell for dagens kardiologiske praksis, fortrinnsvis i større sykehus. Presentasjonen av de 50 kasuistikkene er meget didaktisk, og stoffet representerer et bredt spekter av mer eller mindre akutte tilstander man møter i et sykehus. For hver pasienthistorie gis en kort presentasjon av problemstillingen, etterfulgt av relevante spørsmål man må ta stilling til. Deretter kommer gode og konkrete svar. I mange tilfeller er det i tillegg en fin gjennomgang av sykdomsbildet, med en lærebokmessig fremstilling av patofysiologi, differensialdiagnoser og behandling. Alt virker oppdatert og i tråd med gjeldende retningslinjer. Likevel holder forfatterne seg til pasienthistorien som en rød tråd. Vi får vite hva man gjorde og hvordan det gikk med hver pasient.

Boken vil egne seg meget godt til bruk i internundervisningen ved kardiologiske avdelinger, hvor sentrale emner som arytmier, brystsmerter, klaffefeil, endokarditt, ventilproblematikk, hjertesykdommer hos gravide, aortaaneurismer, lungeembolisme etc. blir gjennomgått. I den kliniske hverdag kan man også bruke den som et oppslagsverk. De 50 kasuistikkene representerer 32 menn og 18 kvinner med en gjennomsnittsalder på 50 år (spredning 16-80 år). Dette innebærer at man også har inkludert flere høyaktuelle kasuistikker med kongenitte vitier hos voksne. Aldersgruppen over 80 år er dessverre ikke inkludert. Det foreligger omfattende dokumentasjon med EKG, ekkoregistreringer, røntgen, CT/MR-funn og myokardperfusjon.

Kvaliteten på EKG og en del ekkobilder er ikke spesielt god. Man har kun tatt med fargelagte bilder pakket sammen mellom s. $210 \mathrm{og} \mathrm{s.} \mathrm{211.} \mathrm{Det} \mathrm{fremgår} \mathrm{ikke} \mathrm{i} \mathrm{innholdsfortegnelsen} \mathrm{hvor}$ disse bildene befinner seg, og man kommer brått på dem midt i kasuistikk nr. 27. Munnen til en fiolinist med høyre ventrikkelutløpstrakttakykardi (kasus 35) er representert med et svart-hvittbilde hvor han skal være blek (under anfall) og ett hvor han skal ha bussende farge(flushing) (etter anfall). I teksten på s. 269 henvises det til fargeplate 13, som ikke er å oppdrive noe sted. Dermed får vi ikke med disse klinisk interessante fargenyanseringer i pasientens sykdomsbilde. Det hadde vært ønskelig med større og mer tydelige EKG-bilder og fargedopplerbilder. Det tar seg ikke ut å presentere fargedopplerregistreringer i svart-hvitt. I 2011 kunne også illustrasjoner fra tredimensjonal ekkokardiografi ha vært på sin plass. Som en liten detalj blir det påpekt at den pacemakerinduserte takykardien i kasus 1 skyldes at atrieflimmer aktiverer atrieledningen og gir en regelmessig takykardi. Selv om et EKG etter anfall viser atrieflimmer, må det vel helst foreligge atrieflutter eller atrietakykardi for å utløse noe sånt. Som kjent er det mange pasienter som har både atrieflimmer og atrieflutter.

Når disse malurtene i begeret er nevnt, er denne boken absolutt å anbefale til bruk i daglig praksis og ikke minst i internundervisningen ved hjerteseksjoner i norske sykehus.

Jan Erik Otterstad

Hjerteseksjonen

Sykehuset i Vestfold

\section{Relevant lærebok for studenter - tilpasset norsk medisin}

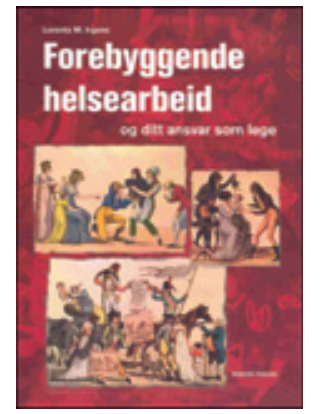

Lorentz M. Irgens

Forebyggende helsearbeid og ditt ansvar som lege

2. utg. 268 s, tab, ill. Bergen: Bodoni Forlag, 2010. Pris NOK 499

ISBN 978-82-7128-557-7

Denne boken kommer nå i sin andre utgave og er ene og alene ført i pennen av forfatteren. Dette er også noe han innledningsvis gjør et poeng av. Lærebøker i store fag har en tendens til å ha mange forfattere, noe som kan gi sprikende form og målgruppe. Her er målet først og fremst å henvende seg til studenter som skal prøve for første gang å få et forhold til faget. Fremstillingen bærer tydelig preg av å være bygd på mange års solid erfaring med studentundervisning og treffer langt på vei målgruppen.

Forfatteren velger med tittelformuleringen «ditt ansvar som lege» å forankre forebyggende helsearbeid til en del av legers kjerneansvar. Enkelte vil hevde at legers ansvar slett ikke er så opplagt når vi beveger oss fra det kliniske og sosiale møtet mellom lege og pasient til møtet mellom legen og de mange, det vil si befolkningen. Andre vil hevde at for å være en god lege for den enkelte pasient vil det antakeligvis hjelpe å ha de mange med seg i tanker og holdninger. Spenningsforholdet mellom den individuelle pasienten og befolkningstilnærmingen er blant de mest sentrale underliggende temaer i moderne medisin, enten vi snakker om samhandlingsreform, kunnskapsbasert medisin, kliniske retningslinjer eller prioritering av helseutgifter. En vesentlig del av også klinisk medisin bærer preg av forebyggende virksomhet. Mange erfarne leger vet dette, men det er ikke opplagt for studenter. De kan lett få det inntrykk at forebygging ikke er en vesentlig del av legerollen. Forfatteren kommer ganske heldig ut av dette gjennom mange gode eksempler, også fra historien. Og innledningsvis forsøker han å nedfelle dette ansvaret $\mathrm{i}$ etiske og juridiske betraktninger. Med tittelen i bakhodet hadde like fullt denne leseren ønsket en enda spenstigere problematisering av denne sentrale dimensjonen. Jeg savnet også mer teoretisk veiledning av studentene, noe som ikke blir mindre aktuelt ved den genetiske revolusjon, individualisert medisin og ulikheter i helse. Når det er sagt, er det få bøker på dette feltet som klarer nettopp det.

Introduksjonen av fagbegreper skjer på en ryddig og systematisk måte. Og presentasjonen av kilder til befolkningsdata og måter å regne risiko er godt beskrevet for studenter. Det er kanskje en litt vel stor vektlegging av helseregistre. Disse kan aldri være et mål i seg selv.

Kapitlene er bygd opp rundt ulike innfallsvinkler til forebygging: historisk bakgrunn, begrunnelse for hvorfor vi skal forebygge, befolkningsdata, tema for forebygging, strategier for forebyggingog organisering av forebygging. Som et supplement er over en tredel av de 268 sidene viet gjengivelse av lovverk av spesiell betydning for forebyggende helsearbeid. Er det virkelig nødvendig med så fyldig og detaljert gjengivelse av lovverket for studenter? Mye av dette stoffet er fagoverskridende og relevant for mange medisinske grener. På bakgrunn av den pågående revisjon av sentralt lovverk kunne forfatteren kanskje vurdert å vente med utgivelsen eller kuttet ut mye av dette stoffet.

Man kan merke noe ufullstendig redaksjonelt arbeid, som når forskerspråklige vendinger blander seg inn i det som ellers er studentvennlig presentasjon av stoffet. Det som virkelig løfter boken, er at den har stor relevans for norske forhold og er formidlet med en stemme. Derfor har jeg ikke problemer med å anbefale den til dette formål.

\section{Øyvind Næss}

Divisjon for epidemiologi

Nasjonalt folkehelseinstitutt 